\title{
Peculiarities of pregnansy and childbirth in patients with a burdened gynecological anamnesis
}

T.P. Andriichuk, A.Ya. Senchuk, V.I. Chermak

Kyiv Medical University, Kyiv, Ukraine

The objective: to study the features of pregnancy, childbirth, postpartum period, fetal status and newborns in patients with a history of chronic salpingo-oophoritis.

Materials and methods. Conducted a retrospective study of 150 birth histories and neonatal development maps. All patients were divided into two groups. The main group includes 100 patients with chronic salpingo-oophoritis, for which they received anti-inflammatory treatment from 1 to 3 times before pregnancy. The control group included 50 pregnant women who did not suffer from chronic salpingo-oophoritis. Results. Our analysis of pregnancy, childbirth, fetal and neonatal status in women with chronic salpingo-oophoritis indicates that such patients have a complicated obstetric and gynecological and somatic history, which forms an unfavorable basic condition of organs and systems, imperfect adaptation to pregnancy, high risk of failure of adaptive reactions. The result is a violation of the formation and development of the mother-placenta-fetus system and, as a consequence, a high level of complications during pregnancy, childbirth and perinatal pathology.

Conclusion. Patients suffering from chronic salpingo-oophoritis should be considered at high risk of possible complications during pregnancy and childbirth. This category of women needs quality preconception training and careful monitoring during pregnancy.

Keywords: burdened gynecological anamnesis, pregnancy, childbirth, postpartum period.

\section{Особливості перебігу вагітності та пологів у пацієнток з обтяженим гінекологічним анамнезом Т.П. Андрійчук, А.Я. Сенчук, В.І. Чермак}

Мета дослідження: вивчення особливостей перебігу вагітності, пологів, післяпологового періоду, стану плодів та новонароджених у пацієнток із хронічним сальпінгоофоритом в анамнезі.

Матеріали та методи. Було проведено ретроспективне вивчення 150 історій пологів і карт розвитку новонароджених. Усі пацієнтки були розподілені на дві групи. До основної групи зараховано 100 пацієнток із хронічним сальпінгоофоритом, з приводу якого вони отримували протизапальне лікування від одного до трьох разів до настання даної вагітності. До контрольної групи увійшли 50 вагітних, які не страждали на хронічний сальпінгоофорит.

Результати. Проведений аналіз особливостей перебігу вагітностей, пологів, стану плодів та новонароджених у жінок із хронічним сальпінгоофоритом свідчить про наявність у таких пацієнток ускладненого акушерсько-гінекологічного і соматичного анамнезу, що формуе несприятливий базисний стан органів і систем організму, недосконалість адаптації його до вагітності і призводить до напруження і високого ризику зриву адаптаційних реакцій. Результатом цього є порушення формування та розвитку системи мати-плацента-плід i, як наслідок, високий рівень ускладнень перебігу вагітності, пологів та перинатальної патології.

Заключення. Пацієнток, які страждають на хронічний сальпінгоофорит, необхідно відносити до групи високого ризику можливого формування ускладнень під час вагітності і пологів. Ця категорія жінок потребує якісної преконцепційної підготовки і ретельного спостереження під час вагітності.

Ключові слова: обтяжений гінекологічний анамнез, вагітність, пологи, післяпологовий період.

\section{Особенности течения беременности и родов у пациенток с отягощенным гинекологическим анамнезом Т.П. Андрейчук, А.Я. Сенчук, В.И. Чермак}

Цель исследования: изучение особенностей течения беременности, родов, послеродового периода, состояния плодов и новорожденных у пациенток с хроническим сальпингоофоритом в анамнезе.

Материалы и методы. Было проведено ретроспективное изучение 150 историй родов и карт развития новорожденных. Все пациентки были распределены на две группы. В основную группу зачислено 100 пациенток с хроническим сальпингоофоритом, по поводу которого они получали противовоспалительное лечение от одного до трех раз до наступления данной беременности. В контрольную группу вошли 50 беременных, которые не страдали на хронический сальпингоофорит.

Pезультаты. Проведенный анализ особенностей течения беременностей, родов, состояния плодов и новорожденных у женщин с хроническим сальпингоофоритом указывает на наличие у таких пациенток осложненного акушерско-гинекологического и соматического анамнеза, который формирует неблагоприятное базисное состояние органов и систем организма, несовершенство адаптации его к беременности и приводит к напряжению и высокому риску срыва адаптационных реакций. Результатом этого является нарушение формирования и развития системы мать-плацента-плод и, как следствие, высокий уровень осложнений течения беременности, родов и перинатальной патологии.

Заключение. Пациенток, которые страдают хроническим сальпингоофоритом, необходимо относить к группе высокого риска возможного формирования осложнений во время беременности и родов. Эта категория женщин требует качественной преконцепционной подготовки и тщательного наблюдения во время беременности.

Ключевые слова: отягощенный гинекологический анамнез, беременность, роды, послеродовой период.

A mong the diseases that impair reproductive function, the Aleading place is occupied by chronic inflammatory diseases of the genital organs. In Ukraine, this pathology in the structure of gynecological morbidity is from 60 to $80 \%$ (Podolsky VV, Dronova VL).

Chronic inflammatory diseases of the female genital organs lead to severe changes in a woman's reproductive system - infertility $(38,9 \%)$, menstrual dysfunction $(42,3 \%)$, polycystic ovaries $(45,7 \%)$, uterine leiomyoma $(3,9 \%)$, hyperplastic pro- cesses of the endometrium $(6,2 \%)$, the formation of joints in the pelvic organs.

Infection of women before pregnancy, inadequate treatment and monitoring of such women can lead to certain problems during pregnancy. To determine the relationship between chronic inflammatory diseases of the genital organs and the frequency of complications of pregnancy and childbirth, we conducted clinical and epidemiological studies in the population of women of childbearing age. The results of these studies 
showed that the most common complications in childbirth in these women were: the threat of abortion (56\%), the threat of premature birth (21\%), premature ejaculation of amniotic fluid (35\%), fetal distress and neonatal asphyxia (58\%), pathological childbirth (36\%), which ended in operative childbirth.

Therefore, the most important problems during pregnancy in case of infection are premature termination of pregnancy and intrauterine infection of the fetus. Premature termination of pregnancy, according to our data, occupies the most important place and is $37 \%$ in case of miscarriage, and $57 \%$ in case of premature birth.

The identified changes are the basis for significant violations in the fetoplacental complex. Thus, in women with infection in $69,8 \%$ of cases there is a decrease in the growth rate of bipaietal size and the average diameter of the abdomen of the fetus, especially in the III trimester of pregnancy. $1 / 3$ of pregnant women showed a decrease in the thickness of the placenta from 30 weeks of pregnancy.

In $14 \%$ of pregnant women there is a tendency to decrease the resistance index and the appearance of areas with persistent blood flow in the vessels of the midbrain artery and in the umbilical arteries, which indicates a violation of the compensatory reactions of the fetus. In $16 \%$ of pregnant women, the resistance index in the umbilical arteries remained significantly elevated.

The content of placental lactogen is also reduced, which weakens its protective effect, aimed at maintaining pregnancy. Hormonal parameters during physiological pregnancy are aimed at its preservation, and at the risk of abortion, in the presence of infection, contribute to the predominance of factors that activate the contractile activity of the myometrium. That is, the existing hormonal interactions at the threat of abortion prematurely prepare the myometrium to respond to stimulants of childbirth.

The second complication most commonly presented during pregnancy in patients with chronic salpingooophoricitis is placental failure. At the present stage, the most informative method of examination is Doppler. The analysis of hemodynamic indicators was characterized by increased resistance of blood flow in the umbilical cord artery, uterine artery, aorta and decreased rates of cerebral artery of the fetus. Changes in the fetoplacenary complex may be causing fetal developmental disorders. Additional methods of diagnosis of placental insufficiency include the method of ultrasonic biometrics in dynamics with the comparison of fetal sizes with the size of gestational age. There is a reliable lag in the development of the fetus. In addition, there is a discrepancy in the thickness of the placenta of the term of pregnancy in the form of thickening or thinning in the echo examination. In the early manifestations of infection with ureaplasm-viral infection, the placenta is 1,5 times relative to the gestacia norm, its structure becomes homogeneous, sound permeability increases significantly, the area of inter-villied space is not determined, and the amount of amistry water increases. In the future, the number of amistene water increases progressively, and the thickness of the placenta decreases.

During childbirth, the main complications are: premature rupture of membranes, abnormalities of childbirth, fetal distress, obstetric bleeding.

Analyzing the perinatal consequences of childbirth, it should be noted the high frequency of intranatal asphyxia of varying severity.

The objective: study of the features of pregnancy, childbirth, postpartum period, fetal status and newborns in patients with a history of chronic salpingo-oophoritis.

\section{MATERIALS AND METHODS}

To study the features of pregnancy, childbirth, postpartum period, fetal status and newborns in patients with a history of chronic salpingo-oophoritis, a retrospective study of 150 birth histories and neonatal development maps was conducted. All patients were divided into two groups. The main group includes 100 patients with chronic salpingo-oophoritis, for which they received anti-inflammatory treatment from 1 to 3 times before the onset of pregnancy. The control group included 50 pregnant women who did not suffer from chronic salpingo-oophoritis.

\section{RESULTS AND DISCUSSION}

The patients we examined in both groups were aged 18 to 35 years, the average age of patients in both groups were representative, as it was in the main group was $29,6 \pm 5,4$ and in the control $-27,9 \pm 6,1$ years.

The main data of the somatic anamnesis of the examined patients are given in table 1.

Analysis of the data in the table indicates that pregnant women with a history of chronic salpingo-oophoritis are dominated by anemia (54,0\%), varicose veins of the lower extremities $(18,0 \%)$. They also have a high infectious index of somatic pathology (childhood infections, cholecystitis, pyelonephritis).

The features of gynecological anamnesis in the examined patients defined by us are given in table 2 .

Analysis of the data shown in table 2 indicates the presence of pregnant women with chronic salpingo-oophoritis data on the violation of the mechanisms of menstrual function, namely, these women were more likely to have $(18,0 \%)$ early menarche (up to 14 years), compared with patients control group $(8,0 \%)$. $8,0 \%$ of patients in the main group and only $2,0 \%$ of the control group complained of late menstruation (after 16 years). The

Data of somatic anamnesis in the examined patients, $(P \pm m)$

\begin{tabular}{|c|c|c|}
\hline The indicator under study & $\begin{array}{c}\text { Main group, } \\
\mathbf{n = 1 0 0}\end{array}$ & $\begin{array}{c}\text { Control group, } \\
\mathbf{n = 5 0}\end{array}$ \\
\hline Children's infectious diseases & $\mathbf{2 6 , 0 \pm 4 , 4}$ & $18,0 \pm 5,4$ \\
\hline Extragenital pathology: & & $14,0 \pm 4,9$ \\
\hline anemia & $54,0 \pm 5,0^{\star}$ & $8,0 \pm 3,8$ \\
\hline heart disease, hypertension & $6,0 \pm 2,4$ & $6,0 \pm 3,4$ \\
\hline varicose veins of the lower extremities & $18,0 \pm 3,8^{\star}$ & $6,0 \pm 4,0$ \\
\hline obesity I and II degree & $28,0 \pm 4,5^{\star}$ & $6,0 \pm 3,4$ \\
\hline diffuse euthyroid goiter & $6,0 \pm 2,4$ & $4,0 \pm 2,8$ \\
\hline pathology of the liver and biliary-excretory tract & $12,0 \pm 3,3$ & $6,0 \pm 3,4$ \\
\hline pathology of the urinary system & $2,0 \pm 4,4$ & \\
\hline
\end{tabular}

Note: * $-p<0,05$ between the indicators of the main and control groups. 
Features of gynecological history in the examined patients, $(P \pm m)$

\begin{tabular}{|c|c|c|}
\hline The indicator under study & Main group, $n=100$ & Control group, $n=50$ \\
\hline $\begin{array}{c}\text { Menarche: } \\
\text { - up to } 14 \text { years } \\
\text { - from } 14 \text { to } 16 \text { years } \\
\text { - older than } 16 \text { years }\end{array}$ & $\begin{array}{c}18,0 \pm 3,8^{\star} \\
74,0 \pm 4,4^{\star} \\
8,0 \pm 2,7\end{array}$ & $\begin{array}{c}6,0 \pm 3,4 \\
92,0 \pm 3,8 \\
2,0 \pm 2,0\end{array}$ \\
\hline $\begin{array}{c}\text { Menstrual irregularities: } \\
\text { - irregular } \\
\text { - algomenorrhea }\end{array}$ & $\begin{array}{c}18,0 \pm 3,8^{*} \\
27,0 \pm 4,4\end{array}$ & $\begin{array}{c}2,0 \pm 2,0 \\
14,0 \pm 4,9\end{array}$ \\
\hline Premenstrual syndrome tension & $25,0 \pm 4,3^{*}$ & $6,0 \pm 3,4$ \\
\hline Sexual dysfunction & $31,0 \pm 4,6^{*}$ & $8,0 \pm 3,8$ \\
\hline Abortions & $64,0 \pm 4,8^{*}$ & $26,0 \pm 6,2$ \\
\hline Spontaneous miscarriages & $10,0 \pm 3,0^{*}$ & 0 \\
\hline Inflammatory diseases of the uterus and appendages & 100,0 & 0 \\
\hline Inflammatory diseases of the vagina & 100,0 & $18,0 \pm 5,4$ \\
\hline Inflammatory diseases and dysplasia of the cervical epithelium & $58,0 \pm 4,9^{*}$ & $16,0 \pm 5,2$ \\
\hline Uterine leiomyoma & $7,0 \pm 2,6^{*}$ & 0 \\
\hline Hyperplastic diseases of the endometrium & $6,0 \pm 2,4^{\star}$ & 0 \\
\hline
\end{tabular}

Note: ${ }^{*}-p<0,05$ between the indicators of the main and control groups.

average duration of the menstrual cycle and the duration of menstruation in women of both groups coincide.

The incidence of sexual dysfunction was also higher in pregnant women with chronic adnexitis compared to healthy women, $31,0 \%$ and $8,0 \%$, respectively.

The frequency of abortions $(64,0 \%$ and $26,0 \%$, respectively) and miscarriages ( $7,0 \%$ and $2,0 \%$, respectively) prevailed in patients of the main group almost three times compared to women in the control group.

From the anamnesis we also learned that $100,0 \%$ of pregnant women in the main group suffered from chronic salpingooophoritis, had episodes of inflammatory diseases of the vagina $(100,0 \%)$ and inflammatory diseases and dysplasia of the cervical epithelium (58,0\%).

Data from the obstetric history (Table 3 ) indicated the representativeness of the groups, as they predominated in groups of women giving birth again, they have almost the same frequency of complicated and operative births.

Studying the features of the current pregnancy, we drew attention to the fact that patients in the control group became pregnant without problems and only $13(26,0 \%)$ of them underwent pre-pregnancy examination, performed correction of the vaginal ecosystem and $7(14,0 \%)$ underwent surgical and cryosurgery) treatment of cervical pathology.

All patients of the main group before the current pregnancy underwent from 2 to 3 courses of anti-inflammatory therapy, which included the use of antibacterial, anti-inflammatory, immunocorrective and enzyme drugs. Pregnancy in all cases came on its own without assistive technology and hor- mone therapy. According to 9 women (18,0\%), they no longer planned the pregnancy and, despite its coincidence, decided to conceive the pregnancy.

Complicated pregnancy was registered in $96,0 \%$ of patients in the main group and in $38,0 \%$ of women in the control group (Table 4).

Characterizing the structure of complications of this pregnancy, it should be noted that every third patient in the main group suffered from vulvovaginitis, moderate anemia (anemia of clinical significance) in these women was recorded in $14,0 \%$ (control $-6,0 \%$ ) of cases. The threat of abortion complicated pregnancy in $28,0 \%$, and the threat of premature birth in $19,0 \%$ of patients in the main group, which is significantly higher than this figure among healthy women $(18,0 \%$ and $6,0 \%$, respectively). Pyelonephritis complicated pregnancy in $23,0 \%$ of pregnant women and only $6,0 \%$ of women in the control group. Mild and moderate preeclampsia was detected in $20,0 \%$ in the main group and $6,0 \%$ in the control group. Low water, which we considered a sign of long-term placental dysfunction, was diagnosed in $14,0 \%$, and high water in $18,0 \%$ of patients in the main group.

The clinical diagnosis of placental dysfunction was established in 33,0\% of pregnant women of the main group and 8,0\% of the control group.

Analysis of biophysical profile of the fetus assessment showed that most often the score of 7 points and below was given to women suffering from chronic salpingo-oophoritis $(26,0 \%)$, in the control $-4,0 \%$.

Doppler moderate hemodynamic disorders were diagnosed

Data of obstetric history in the examined patients, $(P \pm m)$

\begin{tabular}{|c|c|c|}
\hline The indicator under study & $\begin{array}{c}\text { Main group, } \\
\mathbf{n}=\mathbf{1 0 0}\end{array}$ & $\begin{array}{c}\text { Control group, } \\
\mathbf{n = 5 0}\end{array}$ \\
\hline Childbirth: & & $64,0 \pm 6,8$ \\
- one & $67,0 \pm 4,7$ & $2,0 \pm 2,0$ \\
- two or more & $4,0 \pm 2,0$ & $34,0 \pm 6,7$ \\
\hline - absent & $29,0 \pm 4,5$ & $18,0 \pm 5,4$ \\
\hline Complicated childbirth & $22,0 \pm 4,1$ & $4,0 \pm 2,8$ \\
\hline
\end{tabular}

Note: * $-p<0,05$ between the indicators of the main and control groups. 
Complications of pregnancy in the examined patients, $(\mathrm{P} \pm \mathrm{m})$

\begin{tabular}{|c|c|c|}
\hline Complications of pregnancy & Main group, $n=100$ & Control group, $\mathrm{n}=50$ \\
\hline Early gestosis & $12,0 \pm 3,3$ & $10,0 \pm 4,2$ \\
\hline Vulvovaginitis & $31,0 \pm 4,6^{\star}$ & $12,0 \pm 4,6$ \\
\hline Threat of abortion & $28,0 \pm 4,5$ & $18,0 \pm 5,4$ \\
\hline Threat of premature birth & $19,0 \pm 3,9^{*}$ & $6,0 \pm 3,4$ \\
\hline Gestational anemia of moderate severity & $14,0 \pm 3,5$ & $6,0 \pm 3,4$ \\
\hline Pyelonephritis of pregnant women & $23,0 \pm 4,2^{*}$ & $6,0 \pm 3,4$ \\
\hline $\begin{array}{c}\text { Preeclampsia (severity): } \\
\text { - easy } \\
\text { - average } \\
\text { - heavy } \\
\end{array}$ & $\begin{array}{c}16,0 \pm 3,7^{\star} \\
4,0 \pm 2,0 \\
0\end{array}$ & $\begin{array}{c}4,0 \pm 2,8 \\
2,0 \pm 2,0 \\
0\end{array}$ \\
\hline Placental dysfunction & $33,0 \pm 4,7^{*}$ & $8,0 \pm 3,8$ \\
\hline $\begin{array}{l}\text { Biophysical profile of the fetus: } \\
-8-10 \text { points } \\
-7 \text { points and below }\end{array}$ & $\begin{array}{l}74,0 \pm 4,4^{*} \\
26,0 \pm 4,4^{*}\end{array}$ & $\begin{array}{c}96,0 \pm 2,8 \\
4,0 \pm 2,8\end{array}$ \\
\hline $\begin{array}{l}\text { Doppler blood circulation in the vessels of the umbilical cord: } \\
\qquad \begin{array}{c}\text { - norm } \\
\text { - moderate violations } \\
\text { - decompensation }\end{array}\end{array}$ & $\begin{array}{c}71,0 \pm 4,53^{\star} \\
24,0 \pm 4,27^{\star} \\
5,0 \pm 2,18\end{array}$ & $\begin{array}{c}96,0 \pm 2,77 \\
2,0 \pm 1,98 \\
2,0 \pm 1,98\end{array}$ \\
\hline $\begin{array}{l}\text { Changes in the placenta: } \\
\text { - hyperplasia } \\
\text { - hypoplasia } \\
\text { - calcification }\end{array}$ & $\begin{array}{c}21,0 \pm 4,07^{\star} \\
6,0 \pm 2,38 \\
26,0 \pm 4,39^{\star}\end{array}$ & $\begin{array}{l}6,0 \pm 3,36 \\
2,0 \pm 1,98 \\
8,0 \pm 3,84\end{array}$ \\
\hline Low water & $14,0 \pm 3,47^{\star}$ & $2,0 \pm 1,98$ \\
\hline Polyhydramnios & $18,0 \pm 3,84^{*}$ & $6,0 \pm 3,36$ \\
\hline Premature detachment of the normally located placenta & $6,0 \pm 2,38^{\star}$ & 0 \\
\hline $\begin{array}{l}\text { Fetal growth retardation syndrome: } \\
\text { - I degree } \\
\text { - II degree }\end{array}$ & $\begin{array}{c}18,0 \pm 3,84^{*} \\
6,0 \pm 2,38^{*}\end{array}$ & $\begin{array}{c}2,0 \pm 1,98 \\
0\end{array}$ \\
\hline
\end{tabular}

Note: ${ }^{*}-p<0,05$ between the indicators of the main and control groups.

in $24,0 \%$ of primary and $2,0 \%$ of healthy women. The state of decompensated blood circulation in the umbilical vessels was detected in $5,0 \%$ and $2,0 \%$ of patients, respectively.

Morphological manifestations of placental dysfunction were changes in the placenta, which were diagnosed during ultrasound examination. Changes in the form of hyperplasia and hypoplasia of placental tissue, as well as calcifications were found in $53,0 \%$ of patients in the main group, which is much more $(16,0 \%)$ than in the group of healthy pregnant women.

The consequences of placental dysfunction and morphological changes in the placenta were $6(6,0 \%)$ cases of premature detachment of the normally located placenta in the group of patients with chronic salpingo-oophoritis and fetal growth retardation syndrome I degree in $18,0 \%$ and II degree $6,0 \%$ these pregnant women. In the control group fetal growth retardation syndrome was diagnosed in one $(2,0 \%)$ woman.

Thus, the analysis of the peculiarities of pregnancy in patients with chronic salpingo-foritis showed that this pathology is characterized by complications such as vulvovaginitis $(31,0 \%)$, moderate anemia $(14,0 \%)$, the threat of abortion and the threat of premature birth $(47,0 \%)$, pyelonephritis $(23,0 \%)$, low water $(14,0 \%)$ and polyhydramnios $(18,0 \%)$, mild to moderate preeclampsia $(26,0 \%)$ and placental dysfunction $(33,0 \%)$. Objective methods for diagnosing the state of the mother-placenta-fetus system reveal a low score of biophysical profile of the fetus ( 7 and below points) and hemodynamic disorders in umbilical vessels in $26,0 \%$ of patients, morphological changes in placental tissue in $53,0 \%$ of patients
. The clinical consequences of placental dysfunction are fetal growth retardation syndrome $(18,0 \%)$ and premature detachment of the normally located placenta $(6,0 \%)$.

The main complications of childbirth in our examined patients are shown in table 5.

Analysis of the data in the table shows that in pregnant women suffering from chronic salpingo-oophoritis, the number of complications of childbirth (main group) significantly exceeds the frequency of complications in women who have no history of chronic inflammation of the uterine appendages. Namely, premature birth, premature rupture of membranes, pathological preliminary period, primary weakness and uncoordinated labor were registered 2 times, and secondary weakness and distress of the fetus 3 times more often than in healthy women.

One in five patients in the main group was diagnosed with pathology of placental abruption and 6 women $(6,0 \%)$ had premature detachment of the normally located placenta.

Operative methods of childbirth in women of the main group were used almost 5 times more often than in the control group. Among the operations, cesarean section predominated $(29,0 \%)$, the leading indications for which were fetal distress $(48,3 \%)$, secondary weakness $(20,7 \%)$ and uncoordinated labor $(13,8 \%)$.

During childbirth through the natural birth canal, there is a high predisposition of women with chronic salpingo-oophoritis to pathological blood loss ( $>0,5 \%$ of body weight).

Thus, the analysis of the peculiarities of childbirth in patients with chronic salpingo-oophoritis showed that such patients have an increased risk of such complications: prema- 
Complications of childbirth in the examined patients, $(P \pm m)$

\begin{tabular}{|c|c|c|}
\hline Complications of childbirth & Main group, $\mathbf{n = 1 0 0}$ & Control group, $\mathbf{n = 5 0}$ \\
\hline Premature birth & $9,0 \pm 2,9$ & $4,0 \pm 2,8$ \\
\hline Premature rupture of membranes & $21,0 \pm 4,1$ & $10,0 \pm 4,2$ \\
\hline Anomalies of labor: & & $6,0 \pm 3,4$ \\
- pathological preliminary period & $31,0 \pm 4,6^{\star}$ & $6,0 \pm 3,4$ \\
- primary weakness & $11,0 \pm 3,1$ & $4,0 \pm 2,8$ \\
- secondary weakness & $13,0 \pm 3,4^{\star}$ & $6,0 \pm 3,4$ \\
\hline - discoordination & $8,0 \pm 2,7$ & $4,0 \pm 2,8$ \\
\hline Fetal distress & $14,0 \pm 3,5^{\star}$ & 0 \\
\hline Premature placental abruption (during childbirth) & $6,0 \pm 2,4$ & $6,0 \pm 3,4$ \\
\hline Pathology of placental abruption: & $16,0 \pm 3,7$ & $2,0 \pm 2,0$ \\
\hline - placental defect & $4,0 \pm 2,0$ & \\
\hline - tight attachment & & $6,0 \pm 3,4$ \\
- cesarean section & $29,0 \pm 4,5^{\star}$ & $4,0 \pm 2,8$ \\
\hline
\end{tabular}

Note: ${ }^{*}-p<0,05$ between the indicators of the main and control groups.

The average score of newborns on the Apgar scale, $(\mathrm{M} \pm \mathrm{m})$

\begin{tabular}{|c|c|c|}
\hline Surveyed groups & In the 1st minute, points & In the 5th minute, points \\
\hline Pregnant women with chronic salpingo-oophoritis, $n=100$ & $6,34 \pm 0,14^{\star}$ & $7,58 \pm 0,1^{*}$ \\
\hline Control group, $n=50$ & $8,36 \pm 0,09$ & $8,92 \pm 0,12$ \\
\hline
\end{tabular}

Note: ${ }^{*}-p<0,05$ between the indicators of the main and control groups.

The average weight of newborns in the examined groups, $g(M \pm m)$

Pregnant women with chronic salpingo-oophoritis, $n=100$ $2921,6 \pm 244,12^{\star}$ Control group, $\mathrm{n}=50$ $3528,0 \pm 195,42$

Note: ${ }^{*}-p<0,05$ between the indicators of the main and control groups.

ture birth $(9,0 \%)$, premature rupture of membranes $(21,0 \%)$, pathological preliminary period ( $31,0 \%)$, primary $(11,0 \%)$, secondary $(13,0 \%)$ weakness and discoordination $(8,0 \%)$ of labor, fetal distress (14,0\%). Patients with chronic salpingooophoritis have a high risk of placental abruption pathology $(20,0 \%)$, premature placental abruption in childbirth $(2,0 \%)$, increased blood loss $(12,0)$ and operative delivery $(39,0 \%)$.

The condition of newborns in the examined groups was determined by the mean score on the Apgar scale at 1 and 5 minutes after birth and the average body weight at birth.

The obtained data on the average score of newborns on the Apgar scale are shown in table 6.

The analysis of the data given in the table shows a satisfactory condition of children from healthy mothers.

Significant differences were observed in the general condition of children from mothers who suffered from chronic salpingo-ophoritis. Thus, the average score of newborns on the Apgar scale from such mothers was significantly lower than in the control group and was $6,34 \pm 0,14$ in the 1 st and $7,58 \pm 0,1$ in the 5 th minute. The assessment of the condition of newborns on the Apgar scale below 7 points at the 1st minute was registered in $44,0 \%$ of children, in $8,0 \%$ of newborns hypoxicischemic lesions of the CNS were detected.
During pregnancy, $17,0 \%$ of pregnant women with salpingo-oophoritis were diagnosed with fetal growth retardation syndrome. After delivery, the diagnosis was confirmed, which caused a significant difference in the average body weight of newborns in the main and control groups.

Data on the average body weight of newborns in our examined patients are shown in table 7 .

As can be seen from the data in table 3,7, in the control group the average weight of newborns was $3528,0 \pm 195,42$, in the group of women with chronic adnexitis newborns had a significantly lower weight compared to the control group $(\mathrm{p}<0,05)$, which amounted to $2921,6 \pm 244,12$.

Thus, our analysis of the peculiarities of pregnancy, childbirth, fetal status and newborns in women with chronic salpingo-oophoritis indicates the presence of such patients with complicated obstetric and gynecological and somatic history, which forms an unfavorable basic condition of organs and systems, imperfect adaptation to pregnancy stress and high risk of failure of adaptive reactions. The result is a violation of the formation and development of the motherplacenta-fetus system and, as a consequence, a high level of complications during pregnancy, childbirth and perinatal pathology. 


\section{Information about the author}

Andriichuk Tetyana Petrivna - Department of Obstetrics and Gynecology, Kyiv Medical University, Academy of Human Health, 02091, Kyiv, Kharkivske Shosse, 121; tel.: (044) 564-21-65. E-mail: 0503524669@ukr.net

Senchuk Anatoliy Yakovlevich - Department of Obstetrics and Gynecology, Kyiv Medical University, 02099, Kyiv, street Boryspilska, 2; tel.: (044) 560-32-84.E-mail:0509453723@ukr.net

Chermak Volodymyr Ihorovych - Department of Obstetrics and Gynecology, Kyiv Medical University, 02099, Kyiv, street Boryspilska, 2; tel.: (044) 560-32-84. E-mail:0509453723@ukr.net

\section{Відомості про авторів}

Андрійчук Тетяна Петрівна - Кафедра акушерства та гінекології ПВНЗ «Київський медичний університет», КНП «Академія здоров'я людини», 02091, м. Київ, Харківське шосе, 121; тел.: (044) 564-21-65. E-mail: 0503524669@ukr.net

Сенчук Анатолій Якович - Кафедра акушерства та гінекології ПВНЗ «Київський медичний університет», 02099, м. Київ, вул. Бориспільська, 2; тел.: (044) 560-32-84.E-mail:0509453723@ukr.net

Чермак Володимир Ігорович - Кафедра акушерства та гінекології ПВНЗ «Київський медичний університет», 02099, м. Київ, вул. Бориспільська, 2; тел.: (044) 560-32-84. E-mail:0509453723@ukr.net

\section{Сведения об авторах}

Андрейчук Татьяна Петровна - Кафедра акушерства и гинекологии ЧВУЗ «Киевский медицинский университет», КНП «Академия здоровья человека», 02091, г. Киев, Харьковское шоссе, 121; тел.: (044) 564-21-65. E-mail: 0503524669@ukr.net

Сенчук Анатолий Яковлевич - Кафедра акушерства и гинекологии ЧВУЗ «Киевский медицинский университет», 02099, г. Киев, ул. Бориспольская, 2; тел.: (044) 560-32-84. E-mail:0509453723@ukr.net

Чермак Владимир Игоревич - Кафедра акушерства и гинекологии ЧВУЗ «Киевский медицинский университет», 02099, г. Киев, ул. Бориспольская, 2; тел.: (044) 560-32-84.E-mail:0509453723@ukr.net

\section{LITERATURE}

1. Makatsariya AD, Chervenaka FA, Bitsadze VO. 2015. High-risk pregnancy. Moscow: แC Medical Information Agency. :920.

2. Vdovichenko YuP, Bachigin OV et al. 2007. Pre-pregnancy preparation of women with chronic inflammatory diseases of the genitals in the anamnesis. Reproductive health of women. 3(32):130-134.

3. Podolsky W, Podolsky VL et al. 2013. The relationship between the microbiocenosis of urogenital organs and the state of the placenta in pregnant women with the infectious-inflammatory process of the genitals. Collection of scientific works of the Association of Obstetricians and Gynecologists of Ukraine.:315-321.

4. Zabolotna AV. 2016. Optimization of treatment and prevention measures in pregnant women at high risk of placental dysfunction. Current issues of pediatrics, obstetrics and gynecology. 1:60-62.

5. Scherbina NA, Lazurenko W, Sorokolat YuV et al. 2013. A comprehensive approach to the rehabilitation of women with inflammatory diseases of the genitals. Collection of scientific works of the Association of Obstetricians and Gynecologists of Ukraine. :409-411.

6. Markush IM. 2012. Indicators of fetal biophysical profile in pregnant women with a history of salpingo-oophoritis. Current issues of pediatrics, obstetrics and gynecology. 2:99-101.

7. Belkina OV, Gusaklvska OV, Oleshko W. 2013. Medical rehabilitation of women with inflammatory diseases of the pelvic organs of chlamydial etiology. Collection of scientific works of the Associa- tion of Obstetricians and Gynecologists of Ukraine. :31-34.

8. Podolsky W, Dronova VL, Kasatkina TO et al. 2011. Features of pregnancy, childbirth and perinatal disorders in women who have suffered chronic inflammatory diseases of the genitals. Collection of scientific works of the Association of Obstetricians and Gynecologists of Ukraine.:682-685.

9. Romanenko TG, Ignatiuk TN. 2012. Pre-pregnancy training of women from the group of high infectious risk. Protection of motherhood and childhood. 2(20):48.

Статья поступила в редакцию 10.12.2020 